\title{
Comparative study of neuropharmacological, analgesic properties and phenolic profile of Ajwah, Safawy and Sukkari cultivars of date palm (Phoenix dactylifera)
}

\author{
Bassem Yousef Sheikh ${ }^{1}$ - S. M. Neamul Kabir Zihad ${ }^{2}$ - Nazifa Sifat ${ }^{2} \cdot$ Shaikh J. Uddin $^{2}$ • \\ Jamil A. Shilpi ${ }^{2}$ - Omer A. A. Hamdi ${ }^{3}$ Hemayet Hossain ${ }^{4} \cdot$ Razina Rouf $^{2}$ • \\ Ismet Ara Jahan ${ }^{4}$
}

Received: 13 December 2015 / Accepted: 27 July 2016 / Published online: 16 August 2016

(C) The Author(s) 2016. This article is published with open access at Springerlink.com

\begin{abstract}
In addition to the rich nutritional value, date palm is also used in various ethnobotanical practices for the treatment of various disease conditions. Present investigation was undertaken to examine the neuropharmacological and antinociceptive effect of the ethanol extract of three date cultivars growing in Saudi Arabia, namely Ajwah, Safawy and Sukkari. Neuropharmacological effect was observed by pentobarbitone induced sleeping time, open field, and hole board test. Antinociceptive activity was tested by acetic acid induced writhing and hot plate test. The date extracts were also subjected to HPLC analysis to detect the presence of common bioactive polyphenols. All the three date extracts extended the pentobarbitone induced sleeping time, reduced locomotor activity in open field test and reduced exploratory behaviour in hole board test in mice. The extracts also reduced acetic acid induced writhing and delayed response time in hot plate test. The activities were stronger for Ajwah than the other two date cultivars. HPLC analysis indicated the presence of transferulic acid in all three cultivars, while (+)-catechin and (-)-
\end{abstract}

Electronic supplementary material The online version of this article (doi:10.1007/s13596-016-0239-5) contains supplementary material, which is available to authorized users.

Bassem Yousef Sheikh

consultprofsheikh@gmail.com

1 College of Medicine, Taibah University, PO Box 456, Almadinah Almunawarah 41411, Saudi Arabia

2 Pharmacy Discipline, Life Science School, Khulna University, Khulna 9208, Bangladesh

3 Department of Chemistry, Faculty of Science and Technology, Alneelain University, 11121 Khartoum, Sudan

4 BCSIR Laboratories, Bangladesh Council of Scientific and Industrial Research (BCSIR), Dhaka 1205, Bangladesh epicatechin only in Ajwah and Safawy. The observed neuropharmacological and analgesic activity could be partly due to the presence of (+)-catechin, (-)-epicatechin and trans-ferulic acid, three important plant polyphenols well known for their neuroprotective activity and their ability to exert antioxidant activity on brain cells. Present investigation also supports the ethnobotanical use of date palm to provide ameliorating effects in pain and CNS disorders.

Keywords Date palm · Open field test $\cdot$ Hole board test . (+)-catechin $\cdot(-)$-epicatechin $\cdot$ Trans-ferulic acid

\section{Introduction}

The ripe fruits of Phoenix dactylifera L. (Arecaceae), also known as date palm, plays an important role in social and economic perspective of the people living in the oasis of the Middle East by the virtue of its nutritional and pharmacological properties (Baliga et al. 2011). The fruit serves as an important source of nutrition in an arid region hostile to habitation of plants. It is believed that the date palm originated in the Middle East. Due to its rich food value, date was later naturalised in many parts of the world, and at present more than 2000 cultivars of $P$. dactylifera are known to grow around the globe (Guido et al. 2011). Apart from its use as a staple food, date palm enjoys its use in the ethnomedicinal practice for a wide range of ailments. Date palm is used for the treatment of liver disorders (Gill 1992), diabetes (Ziyyat et al. 1997), constipation, diarrhoea (Hmamouchi 1999), and as an aphrodisiac (Zaid and Arias-Jiménez 2002). Date fruits are taken alone or in combination with other ingredients to get relief from asthma (Zaid and Arias-Jiménez 2002), to reduce wrinkling of the skin (Bauza et al. 2001), as an expectorant 
and ameliorating in cough, bronchitis, respiratory disorders, to alleviate headache, to treat sexual debility and to increase immunity (Selvam 2008; Zaid and Arias-Jiménez 2002). Investigations revealed that date palm possesses antioxidant, antimutagenic (Vayalil 2002), antihaemolytic (Abuharfeil et al. 1999), antiviral (Jassim and Naji 2010), antifungal (Shraideh et al. 1998), anti-inflammatory (Mohamed and AlOkabi 2004), antihyperlipidemic (Al-Maiman 2005), hepatoprotective (Al-Qarawi et al. 2004; Sheikh et al. 2014), nephroprotective (Al-Qarawi et al. 2008), gastroprotective (Al-Qarawi et al. 2005), anticancer (Ishurd and Kennedy 2005), immunostimulating (Puri et al. 2000), and gonadotropic (El-Mougy et al. 1991) activity. The date fruit is also rich in pharmacologically important phytochemical constituents including simple pheolics ( $p$-hydroxy benzoic acid, protocatechuic acid, gallic acid, vanillic acid, syringic acid), phenylpropanoids (cinnamic acid, caffeic acid, $o$-caffeoyl shikimic acid, ferulic acid, sinapic acid, $o$-coumaric acid, $p$ coumaric acid) (Mansouri et al. 2005), carotenoids ( $\beta$-carotene, lutein), sterols (cholesterol, campesterol, stigmasterol, $\beta$ sitosterol, isofucosterol) (Kikuchi and Miki 1978), flavonoids and their glycosides (catechin, epi-catechin, quercetin, luteolin, apigenin) (Hong et al. 2006), procyaninidins (Hong et al. 2006), and anthocyanins (Al-Farsi et al. 2005).

The Sukkari date is the best-selling date in Saudi Arabia. These golden-brown dates have patches of lighter colour and are medium or small cone shaped with a firm exterior. This date is characteristically sweet as compared to other cultivars with its chewy flesh. It grows mainly in Qassim, Saudi Arabia. Safawy is another popular date cultivar growing in Almadinah Almunawarah, Saudi Arabia. Safawy is oval shaped soft, moist variety of dates with dark brown texture. Unlike other dates, Ajwah dates are relatively smaller in size. Ajwah is round shaped, soft, dark brown coloured date which looks almost black with fine texture and white wrinkles. Ajwah has special interest to Muslims as it has been mentioned in the Prophetic medicine.

In Ayurveda date palm is known as Kharjura and is indicated for the treatment of psychosis, anxiety, cognitive dysfunction and many of the nervous system disorders (Shanmugapriya and Patwardhan 2012). The fruit is also used alone or in combination to treat sciatica, headache, hemicranias, and applied externally for inflammatory conditions including abscess, boils and ulcers (Shanmugapriya and Patwardhan 2012). Literature survey on date palm revealed that some Chinese and Japanese patented herbal preparations containing date palm as one of the component can be beneficial in treating sleeping disorders ( Katsumichi et al. 1997; Tian 2014). Furthermore, acute toxicity study with date palm extract prior to our project on biological investigation of date extracts revealed extended period of sleep in test animals. All these observations prompted us, as a part of our research on Prophetic medicine (El-Ameen et al. 2015; Halabi and Sheikh
2014; Maulidiani et al. 2015; Taha et al. 2015), to evaluate and compare neuropharmacological effects of two date cultivars growing in Madinah (Ajwah and Safawy) and one growing outside Madinah but within Saudi Arabia (Sukkari).

\section{Materials and methods}

\section{Plant material and extraction}

The dried ripe (in tamar stage) dates were purchased from local date market in Al Madinah AlMunawarah, Saudi Arabia. The dates were identified by taxonomists at Bangladesh National Herbarium where a voucher specimen (DACB 41158) has been submitted for future reference. For easy identification by the readers, images have been given in Fig. 1. The dried dates were mashed with the help of mortar and pestle, soaked in ethanol for 3 days with periodic sonication. The extracts were filtered and dried using a rotary vacuum evaporator at $45^{\circ} \mathrm{C}$ under reduced pressure to get semisolid masses. The extracts were further freeze dried to get the crude extract.

\section{Test animals}

Young Swiss Albino mice of 4-5 weeks old and weighing 20$25 \mathrm{~g}$ were purchased from the Animal Resources Branch of International Centre for Diarrhoeal Disease Research, Bangladesh (ICCDR,B). They were acclimatised with the laboratory condition (temperature: $25 \pm 2{ }^{\circ} \mathrm{C}$, relative humidity: $56-60 \%, 12 \mathrm{~h}$ dark-light cycle) before the commencement of the pharmacological experiments.

\section{Chemicals and drugs}

Arbutin, benzoic acid, caffeic acid, (+)-catechin, transcinnamic acid, $p$-coumaric acid, ellagic acid, (-)-epicatechin, trans-ferulic acid, gallic acid, hydroquinone, kaempferol, myricetin, quercetin, rosmarinic acid, rutin, syringic acid, vanillic acid, and vanillin were purchased from SigmaAldrich (St. Louis, MO, USA). Reference drugs were generously provided by Beximco Pharmaceuticals Ltd. Bangladesh (diclofenac sodium and caffeine), Popular Pharmaceuticals
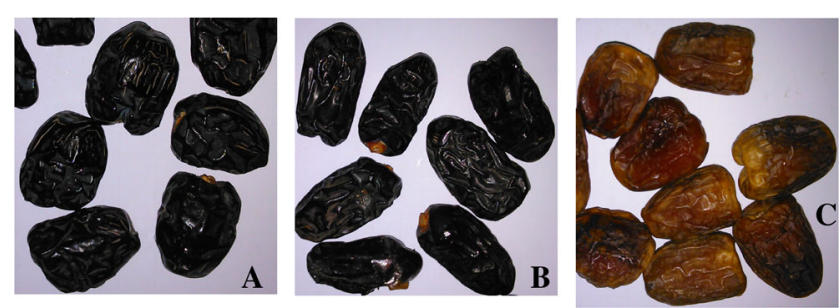

Fig. 1 Pictures of date palms. a: Ajwah; b: Safawy; c: Sukkari 
Ltd. Bangladesh (morphine) and Incepta Pharmaceuticals Ltd. Bangladesh (pentobarbitone).

\section{Acute toxicity test}

Test mice divided into different groups containing 6 mice of either sex were treated with graded doses $(62.5-4000 \mathrm{mg} / \mathrm{kg}$ body weight) of date palm extract while the control group received control vehicle ( $1 \%$ Tween 80 in water) orally. The animals were observed for $72 \mathrm{~h}$ and mortality, general signs and symptoms of toxicity were recorded for each group (Lorke 1983).

\section{Grouping and dosing}

Animals of either sex were randomly divided into four groups, each comprising of six animals. Control group received vehicle (1\% Tween 80 in water) orally at a volume of $10 \mathrm{ml} / \mathrm{kg}$. Test groups were pre-treated orally with three date extracts at the doses of 250 and $500 \mathrm{mg} / \mathrm{kg}$, while positive control group received reference drug.

\section{Pentobarbitone-induced sleeping time test}

Test groups were orally treated with the three date extracts at the aforementioned doses while control and positive control group received control vehicle and diazepam $(5 \mathrm{mg} / \mathrm{kg}$, p.o.), respectively. After thirty minutes, pentobarbitone $(50 \mathrm{mg} / \mathrm{kg}$, i.p.) was administered to each mouse to induce sleep. The latent period for the onset of sleep, and the duration of sleep was recorded (Shilpi et al. 2004).

\section{Open field test}

Test mice and control mice were placed on the floor of an open field of the dimension $100 \mathrm{~cm} \times 100 \mathrm{~cm} \times 40 \mathrm{~cm}$, divided in squares coloured black and white. The number of squares visited by each group was recorded for $3 \mathrm{~min}$ after every thirty minutes starting from the time of extract administration and continued for a period of $4 \mathrm{~h}$ (Shilpi et al. 2004).

\section{Hole board test}

Each mouse from the control, test and positive control group was placed in the hole board having 16 evenly placed holes. Head dipping of the mouse through the holes was recorded for $2 \mathrm{~min}$ on every $30 \mathrm{~min}$ for a period of $2 \mathrm{~h}$ starting from the time of extract administration (Mondal et al. 2014).

\section{Acetic acid induced writhing test}

Acetic acid $(0.7 \%, 10 \mathrm{ml} / \mathrm{kg})$ was administered intraperitoneally to each mouse $30 \mathrm{~min}$ after the administration of control vehicle, date extracts and diclofenac sodium ( $25 \mathrm{mg} / \mathrm{kg}$, p.o.). After 5 min of acetic acid administration, number of writhing by each group was recorded for $10 \mathrm{~min}$ (Mondal et al. 2014).

\section{Hot-plate test}

Control vehicle, date extracts and morphine $(5 \mathrm{mg} / \mathrm{kg}$, i.p.) treated mice were placed on a hot plate maintained at the temperature of $55 \pm 0.5^{\circ} \mathrm{C}$ on every $30 \mathrm{~min}$ starting from the time of extract administration and continued for a period of $2 \mathrm{~h}$ to record response time, i.e., the time required for paw licking or jumping. To avoid any injury or accidental paw damage of the mouse, a cut-off point of $15 \mathrm{~s}$ was maintained (Mondal et al. 2014).

\section{HPLC analysis for polyphenolic constituents}

Detection of the major polyphenolic compounds present in the date extracts was conducted by HPLC analysis on a DionexUltiMate 3000 Rapid Separation LC system (Thermo Fisher Scientific Inc., MA, USA) equipped with a quaternary rapid separation pump (LPG-3400RS), acclaim ${ }^{\circledR} \mathrm{C}_{18}$ column $(4.6 \times 250 \mathrm{~mm} ; 5 \mu \mathrm{m}$, Dionex USA $)$ housed in a temperature-controlled column compartment (TCC-3000) maintained at $30{ }^{\circ} \mathrm{C}$, and photodiode array detector (DAD-3000RS) (Chuanphongpanich and Phanichphant 2006; Islam et al. 2014). Separation was done using a gradient elution programme consisting of 5\% A95\% B 0-9 $\mathrm{min}, 10 \% \mathrm{~A} 80 \% \mathrm{~B} 10 \% \mathrm{C} 10-19 \mathrm{~min}$, $20 \% \mathrm{~A} / 60 \% \mathrm{~B} / 20 \% \mathrm{C} 20-30 \mathrm{~min}$, followed by flushing and further equilibriation with $100 \% \mathrm{~A}$ for $5 \mathrm{~min}$; where $\mathrm{A}$, B and $\mathrm{C}$ are acetonitrile, acetic acid solution of $\mathrm{pH} 3$ and methanol, respectively. For detection, photodiode array detector was set to the range of $200-700 \mathrm{~nm}$ for the entire

Table 1 Effects of three date extracts on pentobarbitone induced sleeping time in mice

\begin{tabular}{lllll}
\hline $\begin{array}{l}\text { Treatment } \\
(n=5)\end{array}$ & $\begin{array}{l}\text { Dose } \\
(\mathrm{mg} / \mathrm{kg})\end{array}$ & $\begin{array}{l}\text { Route of } \\
\text { administration }\end{array}$ & $\begin{array}{l}\text { Onset of } \\
\text { sleep (min) }\end{array}$ & $\begin{array}{l}\text { Duration of } \\
\text { sleep (min) }\end{array}$ \\
\hline $\begin{array}{c}\text { Control }(1 \% \\
\text { Tween } 80 \text { in } \\
\text { water) }\end{array}$ & $10 \mathrm{ml} / \mathrm{kg}$ & p.o. & $9.6 \pm 0.55$ & $74.0 \pm 2.0$ \\
$\begin{array}{l}\text { Diazepam } \\
\text { Ajwah }\end{array}$ & 5 & i.p. & $3.6 \pm 0.34^{\mathrm{d}}$ & $140 \pm 2.2^{\mathrm{f}}$ \\
& 250 & p.o. & $7.8 \pm 0.36^{\mathrm{cd}}$ & $90 \pm 2.4^{\mathrm{ce}}$ \\
Safawy & 500 & p.o. & $6.3 \pm 0.35^{\text {ad }}$ & $110 \pm 2.2^{\mathrm{cf}}$ \\
& 250 & p.o. & $8.1 \pm 0.39^{\mathrm{c}}$ & $86 \pm 2.3^{\mathrm{cd}}$ \\
Sukkari & 500 & p.o. & $7.0 \pm 0.35^{\mathrm{cd}}$ & $100 \pm 3.0^{\mathrm{cf}}$ \\
& 250 & p.o. & $8.6 \pm 0.34^{\mathrm{c}}$ & $83 \pm 1.6$ \\
& 500 & p.o. & $7.4 \pm 0.24^{\mathrm{cd}}$ & $97 \pm 2.6^{\mathrm{ce}}$ \\
\hline
\end{tabular}

${ }^{\mathrm{a}} p<0.05$ vs. diazepam, ${ }^{\mathrm{b}} p<0.01$ vs. diazepam, ${ }^{\mathrm{c}} p<0.001$ vs. diazepam, ${ }^{\mathrm{d}} p<0.05$ vs. control, ${ }^{\mathrm{e}} p<0.01$ vs.control, ${ }^{\mathrm{f}} p<0.001$ vs. control 
Table 2 Effects of three date extracts on open field test in mice

\begin{tabular}{|c|c|c|c|c|c|c|c|}
\hline \multirow[t]{2}{*}{ Treatment $(n=5)$} & \multirow[t]{2}{*}{ Dose (mg/kg) } & \multicolumn{6}{|c|}{ Number of movement } \\
\hline & & $0 \mathrm{~min}$ & $30 \mathrm{~min}$ & $60 \mathrm{~min}$ & $90 \mathrm{~min}$ & $120 \mathrm{~min}$ & $180 \mathrm{~min}$ \\
\hline Control & $10 \mathrm{ml} / \mathrm{kg}$ & $133.2 \pm 2.6$ & $123.4 \pm 3.23$ & $113.0 \pm 2.2$ & $104.2 \pm 2.3$ & $106.8 \pm 4.7$ & $95.8 \pm 2.0$ \\
\hline Diazepam & 5 & $126.2 \pm 3.7$ & $39.6 \pm 1.7^{\mathrm{f}}$ & $30.2 \pm 1.0^{\mathrm{f}}$ & $28.2 \pm 2.5^{\mathrm{f}}$ & $29.4 \pm 1.2^{\mathrm{f}}$ & $27.6 \pm 1.2^{\mathrm{d}}$ \\
\hline \multirow[t]{2}{*}{ Ajwah } & 250 & $128.0 \pm 2.0$ & $89.4 \pm 2.2^{\mathrm{cf}}$ & $74.6 \pm 2.7^{\mathrm{cf}}$ & $73.2 \pm 1.6^{\mathrm{ce}}$ & $75.4 \pm 2.8^{\mathrm{cf}}$ & $81.0 \pm 3.0^{\mathrm{cd}}$ \\
\hline & 500 & $129.2 \pm 2.2$ & $84.4 \pm 1.8^{\mathrm{cf}}$ & $71.6 \pm 1.9^{\mathrm{cf}}$ & $67.0 \pm 1.4^{\mathrm{cf}}$ & $71.0 \pm 1.0^{\mathrm{cf}}$ & $74.2 \pm 1.7^{\mathrm{cf}}$ \\
\hline \multirow[t]{2}{*}{ Safawy } & 250 & $139.4 \pm 2.6$ & $91.6 \pm 3.9^{\mathrm{ce}}$ & $78.0 \pm 3.1^{\mathrm{cf}}$ & $76.0 \pm 3.8^{\mathrm{cf}}$ & $79.0 \pm 2.5^{\mathrm{ce}}$ & $84.4 \pm 3.7^{\mathrm{cd}}$ \\
\hline & 500 & $133.0 \pm 3.0$ & $85.4 \pm 1.9^{\mathrm{cf}}$ & $73.4 \pm 1.8^{\mathrm{ce}}$ & $70.2 \pm 1.9^{\mathrm{cf}}$ & $75.2 \pm 2.4^{\mathrm{cf}}$ & $80.2 \pm 3.8^{\mathrm{cf}}$ \\
\hline \multirow[t]{2}{*}{ Sukkari } & 250 & $129.4 \pm 4.5$ & $93.2 \pm 2.8^{\mathrm{cf}}$ & $82.2 \pm 2.8^{\mathrm{cf}}$ & $75.4 \pm 2.7^{\mathrm{ce}}$ & $73.0 \pm 2.8^{\mathrm{cf}}$ & $82.2 \pm 1.9^{\text {ce }}$ \\
\hline & 500 & $137.2 \pm 3.6$ & $86.2 \pm 3.7^{\mathrm{cf}}$ & $77.0 \pm 3.3^{\mathrm{cf}}$ & $72.4 \pm 3.3^{\mathrm{cf}}$ & $69.4 \pm 2.7^{\mathrm{cf}}$ & $79.2 \pm 2.2^{\mathrm{ce}}$ \\
\hline
\end{tabular}

${ }^{\mathrm{a}} p<0.05$ vs. diazepam, ${ }^{\mathrm{b}} p<0.01$ vs. diazepam, ${ }^{\mathrm{c}} p<0.001$ vs. diazepam, ${ }^{\mathrm{d}} p<0.05$ vs. control, ${ }^{\mathrm{e}} p<0.01$ vs. control, ${ }^{\mathrm{f}} p<0.001$ vs. control

experimental period while UV detector was set to $280 \mathrm{~nm}$ for 0 $18 \mathrm{~min}, 320 \mathrm{~nm}$ for $19-24 \mathrm{~min}$, and $380 \mathrm{~nm}$ for 25-30 $\mathrm{min}$. Calibration curve was prepared using a standard solution of methanol containing arbutin $(5 \mu \mathrm{g} / \mathrm{ml})$, benzoic acid $(8 \mu \mathrm{g} / \mathrm{ml})$, caffeic acid $(3 \mu \mathrm{g} / \mathrm{ml}),(+)$-catechin $(10 \mu \mathrm{g} / \mathrm{ml})$, transcinnamic acid $(1 \mu \mathrm{g} / \mathrm{ml}), p$-coumaric acid $(2 \mu \mathrm{g} / \mathrm{ml})$, ellagic acid $(10 \mu \mathrm{g} / \mathrm{ml}),(-)$-epicatechin $(5 \mu \mathrm{g} / \mathrm{ml})$, trans-ferulic acid (3 $\mu \mathrm{g} / \mathrm{ml})$, gallic acid $(4 \mu \mathrm{g} / \mathrm{ml})$, hydroquinone $(4 \mu \mathrm{g} / \mathrm{ml})$, kaempferol (2 $\mu \mathrm{g} / \mathrm{ml})$, myricetin $(4 \mu \mathrm{g} / \mathrm{ml})$, quercetin (2 $\mu \mathrm{g} / \mathrm{ml})$, rosmarinic acid $(4 \mu \mathrm{g} / \mathrm{ml})$, rutin $(6 \mu \mathrm{g} / \mathrm{ml})$, syringic acid $(3 \mu \mathrm{g} / \mathrm{ml})$, vanillic acid $(4 \mu \mathrm{g} / \mathrm{ml})$, and vanillin $(3 \mu \mathrm{g} / \mathrm{ml})$. Test solutions for date extracts were prepared at a concentration of $5 \mathrm{mg} / \mathrm{ml}$ in methanol. The injection volume was $20 \mu \mathrm{l}$ for standard or extract solutions, and the experiments were conducted with a flow rate of $1 \mathrm{ml} / \mathrm{min}$.

\section{Statistical analysis}

Results were expressed as mean \pm SEM. One-way or twoway ANOVA followed by Bonferroni's test was done for statistical analysis and results were considered significant when $p<0.05$.

\section{Results}

\section{Results of acute toxicity test}

No mortality or signs or symptoms of toxicities were observed for any of the date extracts under investigation even at the highest dose $(4.0 \mathrm{~g} / \mathrm{kg})$ tested. However, at higher doses, the mice showed extended sleeping tendency which persisted up to $48 \mathrm{~h}$.

\section{Results of pentobarbitone-induced sleeping time test}

All the date extracts reduced the time for the onset of sleep and increased the duration of sleep as compared to the control with the extent of intensity relatively higher with Ajwah than Safawy or Sukkari, but less than that of diazepam. All the results were statistically significant (Table 1).

\section{Results of open field test}

In the open field test, the extracts showed a decrease in the movements in test mice as compared to control. The decrease

Table 3 Effects of three date extracts on hole board test in mice

\begin{tabular}{|c|c|c|c|c|c|c|c|}
\hline \multirow[t]{2}{*}{ Treatment $(n=5)$} & \multirow[t]{2}{*}{ Dose (mg/kg) } & \multicolumn{6}{|c|}{ Number of head dipping } \\
\hline & & $0 \mathrm{~min}$ & $30 \mathrm{~min}$ & $60 \mathrm{~min}$ & $90 \mathrm{~min}$ & $120 \mathrm{~min}$ & $180 \min$ \\
\hline Control & $10 \mathrm{ml} / \mathrm{kg}$ & $19.2 \pm 0.9$ & $21.4 \pm 1.3$ & $27.0 \pm 1.4$ & $29.4 \pm 1.6$ & $31.0 \pm 1.4$ & $33.4 \pm 1.3$ \\
\hline Diazepam & 5 & $20.2 \pm 1.0$ & $11.4 \pm 0.9^{\mathrm{f}}$ & $6.0 \pm 1.0^{\mathrm{f}}$ & $6.4 \pm 0.8^{\mathrm{f}}$ & $6.2 \pm 0.6^{\mathrm{f}}$ & $7.4 \pm 0.5^{\mathrm{f}}$ \\
\hline \multirow[t]{2}{*}{ Ajwah } & 250 & $20.4 \pm 0.8$ & $16.8 \pm 1.1^{\mathrm{cd}}$ & $14.6 \pm 0.8^{\mathrm{cf}}$ & $13.8 \pm 0.8^{\mathrm{cf}}$ & $17.0 \pm 0.7^{\mathrm{ce}}$ & $23.8 \pm 0.7^{\mathrm{ce}}$ \\
\hline & 500 & $20.4 \pm 1.2$ & $16.4 \pm 1.2^{\text {be }}$ & $12.8 \pm 0.9^{\mathrm{cf}}$ & $12.4 \pm 0.8^{\mathrm{cf}}$ & $14.2 \pm 1.0^{\mathrm{cf}}$ & $19.8 \pm 0.9^{\mathrm{cf}}$ \\
\hline \multirow[t]{2}{*}{ Safawy } & 250 & $19.8 \pm 1.0$ & $17.4 \pm 0.9^{\mathrm{cd}}$ & $18.0 \pm 0.7^{\mathrm{cf}}$ & $16.0 \pm 0.5^{\mathrm{cf}}$ & $19.4 \pm 0.9^{\mathrm{ce}}$ & $23.4 \pm 1.0^{\mathrm{cd}}$ \\
\hline & 500 & $19.2 \pm 0.8$ & $17.0 \pm 1.0^{\mathrm{ce}}$ & $15.0 \pm 0.9^{\mathrm{cf}}$ & $13.4 \pm 1.0^{\mathrm{cf}}$ & $16.2 \pm 1.1^{\mathrm{cf}}$ & $20.4 \pm 0.9^{\mathrm{cf}}$ \\
\hline \multirow[t]{2}{*}{ Sukkari } & 250 & $20.4 \pm 1.0$ & $18 \pm 0.7^{\mathrm{cd}}$ & $18.4 \pm 0.8^{\mathrm{ce}}$ & $17.2 \pm 0.7^{\mathrm{cf}}$ & $20.4 \pm 0.8^{\mathrm{cf}}$ & $23.2 \pm 0.9^{\mathrm{cd}}$ \\
\hline & 500 & $20.2 \pm 0.9$ & $17.2 \pm 1.0^{\mathrm{cd}}$ & $15.4 \pm 0.9^{\mathrm{cf}}$ & $14.6 \pm 0.7^{\mathrm{cf}}$ & $16.6 \pm 1.1^{\mathrm{cf}}$ & $21.0 \pm 1.0^{\mathrm{ce}}$ \\
\hline
\end{tabular}

${ }^{\mathrm{a}} p<0.05$ vs. diazepam, ${ }^{\mathrm{b}} p<0.01$ vs. diazepam, ${ }^{\mathrm{c}} p<0.001$ vs. diazepam, ${ }^{\mathrm{d}} p<0.05$ vs. control, ${ }^{\mathrm{e}} p<0.01$ vs. control, ${ }^{\mathrm{f}} p<0.001$ vs. control 
Table 4 Effects of three date extracts on acetic acid induced writhing in mice

\begin{tabular}{lll}
\hline $\begin{array}{l}\text { Treatment } \\
(n=5)\end{array}$ & Dose $(\mathrm{mg} / \mathrm{kg})$ & Number of writhing \\
\hline Control (1 \% Tween 80 in water) & $10 \mathrm{ml} / \mathrm{kg}$ & $33.0 \pm 1.0$ \\
Diclofenac sodium & 25 & $9.4 \pm 0.5^{\mathrm{d}}$ \\
Ajwah & 250 & $23.0 \pm 0.4^{\mathrm{cd}}$ \\
& 500 & $21.0 \pm 0.6^{\mathrm{cd}}$ \\
Safawy & 250 & $24.0 \pm 0.4^{\mathrm{cd}}$ \\
& 500 & $22.0 \pm 0.5^{\mathrm{cd}}$ \\
Sukkari & 250 & $25.0 \pm 0.7^{\mathrm{cd}}$ \\
& 500 & $23.0 \pm 0.6^{\mathrm{cd}}$ \\
\hline
\end{tabular}

${ }^{\mathrm{a}} p<0.05$ vs. diclofenac sodium, ${ }^{\mathrm{b}} p<0.01$ vs. diclofenac sodium, ${ }^{\mathrm{c}} p<0.001$ vs. diclofenac sodium, ${ }^{\mathrm{d}} p<0.001$ vs. control

in the movement was prominent from $30 \mathrm{~min}$ until $120 \mathrm{~min}$, with the effect gradually fading at $180 \mathrm{~min}$. Diazepam, used as positive control showed similar results but the effect was stronger as compared to the three dates extracts. All the results were statistically significant (Table 2).

\section{Results of hole board test}

In the hole board test, a decrease in the number of head dipping was observed for the test mice. Although, the effect was not as strong as that of diazepam, the results of the date extracts were significantly different when compared to control and the effect of Ajwah extract was stronger than the other two date extracts (Table 3 ).

\section{Results of acetic acid induced writhing}

All three date extracts significantly reduced acetic acid induced writhing in test mice as compared to the control. Diclofenac sodium, used as the positive control in this study showed strong analgesic activity (Table 4).

\section{Results of hot plate test}

The response time in test mice was extended by all the three date extracts and morphine as compared to the control and the results were statistically significant. Maximum effect was observed one hour after the treatment, which gradually faded at the end of the experiment ( $2 \mathrm{~h}$ ) (Table 5).

\section{Results of HPLC analysis}

Results of HPLC analysis of the standards and three date cultivars under investigation are presented in Figs. 2, 3, 4 and 5 and Table 6 . All the three date cultivars showed the presence of trans-ferulic acid with its highest content in Ajwah. Among other phenolic components, (+)-catechin and $(-)$-epicatechin were present in Ajwah and Safawy but not in Sukkari. In contrast, caffeic acid and $p$-coumaric acid were present only in Sukkari. Rosmarinic acid was only present in Ajwah.

\section{Discussion}

The fruits of date palm have a long history of its use in traditional medicine. While date palm is reported to be used in headache, recent study suggests that the fruits have cerebroprotective activity in mice suffering from cerebral ischemia (Kalantaripour et al. 2012). It was also found to exhibit neuroprotective activity in mice with ischemia induced bilateral common carotid artery occlusion (Pujari et al. 2011). Presence of flavonoids, sterols and ascorbic acid was credited for the observed ameliorating effect. Present investigation was done to evaluate neuropharmacological and antinociceptive effects of three cultivars of date palm, namely Ajwah, Safawy, and Sukkari. Extended period of sleeping by the test mice in acute toxicity test suggests that the effect was not a 'post lunch dip' which might occur with high sugar content of
Table 5 Effects of three date extracts on hot plate test in mice

\begin{tabular}{|c|c|c|c|c|c|c|}
\hline \multirow[t]{2}{*}{ Treatment $(n=5)$} & \multirow{2}{*}{$\begin{array}{l}\text { Dose } \\
(\mathrm{mg} / \mathrm{kg})\end{array}$} & \multicolumn{5}{|c|}{ Response time (sec) } \\
\hline & & $0 \min$ & $30 \mathrm{~min}$ & $60 \mathrm{~min}$ & $90 \mathrm{~min}$ & $120 \mathrm{~min}$ \\
\hline Control & $10 \mathrm{ml} / \mathrm{kg}$ & $4.6 \pm 0.13$ & $4.5 \pm 0.26$ & $4.5 \pm 0.18$ & $4.2 \pm 0.32$ & $4.4 \pm 0.15$ \\
\hline Morphine & 5 & $4.7 \pm 0.15$ & $8.9 \pm 0.16^{\mathrm{f}}$ & $11.4 \pm 0.40^{\mathrm{f}}$ & $11.0 \pm 0.36^{\mathrm{f}}$ & $8.7 \pm 0.20^{\mathrm{f}}$ \\
\hline \multirow[t]{2}{*}{ Ajwah } & 250 & $4.3 \pm 0.10$ & $5.7 \pm 0.24^{\mathrm{cf}}$ & $5.9 \pm 0.14^{\mathrm{cf}}$ & $5.0 \pm 0.10^{\mathrm{ce}}$ & $4.4 \pm 0.15^{\mathrm{c}}$ \\
\hline & 500 & $4.3 \pm 0.1$ & $5.9 \pm 0.27^{\mathrm{cf}}$ & $7.0 \pm 0.19^{\mathrm{cf}}$ & $6.6 \pm 0.20^{\mathrm{cf}}$ & $5.2 \pm 0.10^{\mathrm{cd}}$ \\
\hline \multirow[t]{2}{*}{ Safawy } & 250 & $4.6 \pm 0.15$ & $5.7 \pm 0.17^{\mathrm{cf}}$ & $6.0 \pm 0.13^{\mathrm{cf}}$ & $5.3 \pm 0.19^{\mathrm{cf}}$ & $4.3 \pm 0.14^{\mathrm{c}}$ \\
\hline & 500 & $4.6 \pm 0.15$ & $6.6 \pm 0.20^{\mathrm{cf}}$ & $7.3 \pm 0.14^{\mathrm{cf}}$ & $6.5 \pm 0.21^{\mathrm{cf}}$ & $4.5 \pm 0.20^{\mathrm{c}}$ \\
\hline \multirow[t]{2}{*}{ Sukkari } & 250 & $4.2 \pm 0.12$ & $5.2 \pm 0.12^{\mathrm{c}}$ & $5.6 \pm 0.15^{\mathrm{cf}}$ & $4.9 \pm 0.23^{\mathrm{c}}$ & $4.3 \pm 0.17^{\mathrm{c}}$ \\
\hline & 500 & $4.4 \pm 0.14$ & $5.9 \pm 0.17^{\mathrm{cf}}$ & $6.9 \pm 0.15^{\mathrm{cf}}$ & $5.8 \pm 0.12^{\mathrm{cf}}$ & $4.5 \pm 0.17^{\mathrm{cf}}$ \\
\hline
\end{tabular}

${ }^{\mathrm{a}} p<0.05$ vs. morphine, ${ }^{\mathrm{b}} p<0.01$ vs. morphine, ${ }^{\mathrm{c}} p<0.001$ vs. morphine, ${ }^{\mathrm{d}} p<0.05$ vs. control, ${ }^{\mathrm{e}} p<0.01$ vs. control, ${ }^{\mathrm{f}} p<0.001$ vs. control 
Fig. 2 HPLC chromatogram of a standard mixture of polyphenolic compounds. Peaks 1: arbutin; 2: gallic acid; 3 : hydroquinone; 4 : (+)-catechin; 5: vanillic acid; 6: caffeic acid; 7: syringic acid; 8 : (-)-epicatechin; 9: vanillin; 10: pcoumaric acid; 11: trans-ferulic acid; 12: rutin; 13: ellagic acid; 14: benzoic acid; 15 : rosmarinic acid; 16: myricetin; 17: quercetin; 18: trans-cinnamic acid; 19 : kaempferol

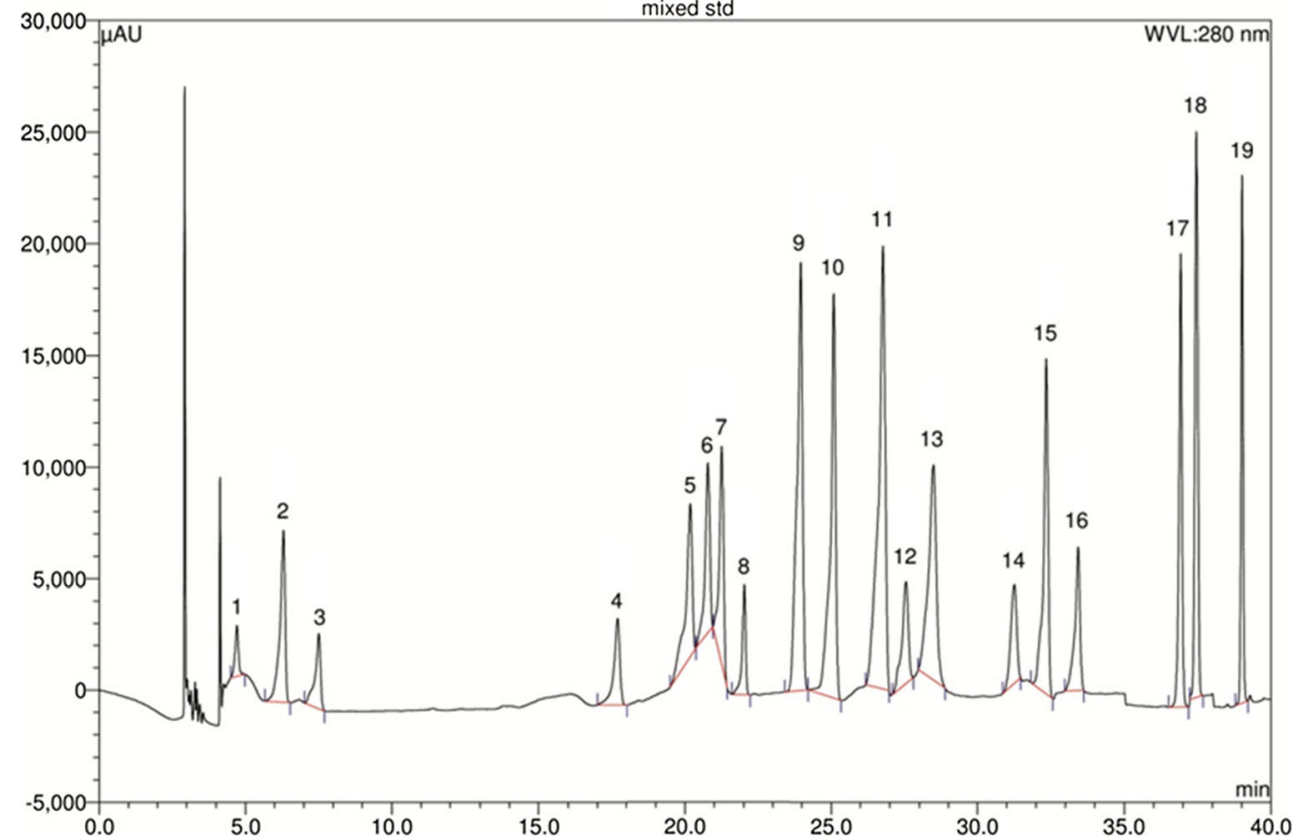

date palm extracts. All these extracts showed an increase in the pentobarbitone induced sleeping time in mice. Pentobarbitone is a barbiturate type sedative and hypnotic agent, which acts through allosteric modification of GABA receptor resulting in postsynaptic inhibition (ffrench-Mullen et al. 1993). Neuroactive agents, depending on their stimulating or depressing effect, can increase or decrease the duration of pentobarbitone induced sleep in test animal. In our present study, all the date extracts decreased the latency for the onset of sleep, as well as increased the duration of sleep indicating that the extracts might have some sedative effect on CNS. Open field and hole board tests are important but simple ways of determining CNS effect of any agent (Takagi et al. 1971; Uddin et al. 2006). Results of the present investigation shows a decrease in locomotor activity in test mice treated with date extracts suggesting that the date extracts might have decreased CNS activity in test mice. In both open field and hole board test, the effect was highest with Ajwah extract. Present investigation suggests a relaxing effect in the test mice treated with date extracts. It is well established that antioxidants play an important role in reducing oxidative stress in brain and provide neuroprotective effect (Giacalone et al. 2011; Mohamadin et al. 2010; Sheikh and Mohamadin 2012; Wang et al. 2006). In our present investigation, two important
Fig. 3 HPLC chromatogram of Ajwah date extract. Peaks 1: (+)catechin; 2: (-)-epicatechin; 3 : trans-ferulic acid; 4: rosmarinic acid

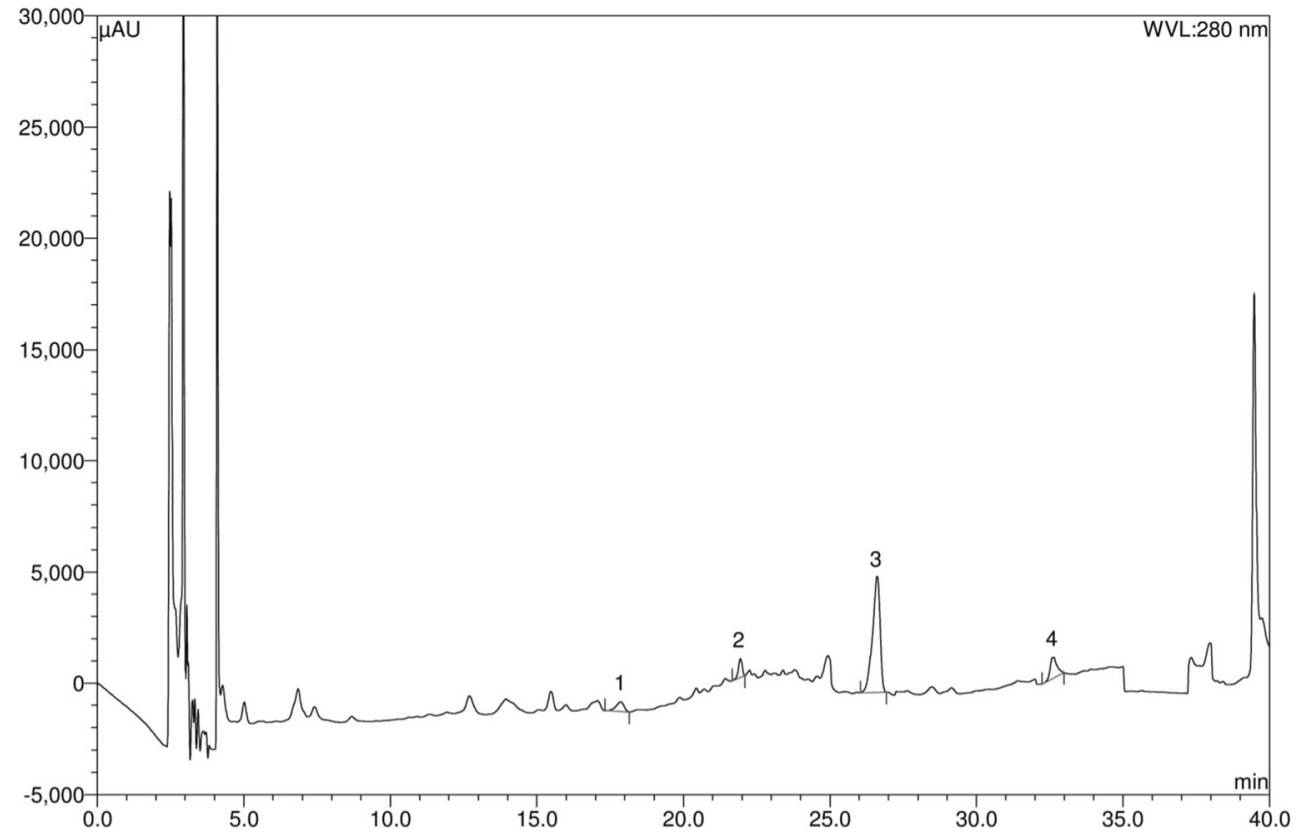


Fig. 4 HPLC chromatogram of safawy date extract. Peaks 1: (+)catechin; 2: (-)-epicatechin; 3 : trans-ferulic acid

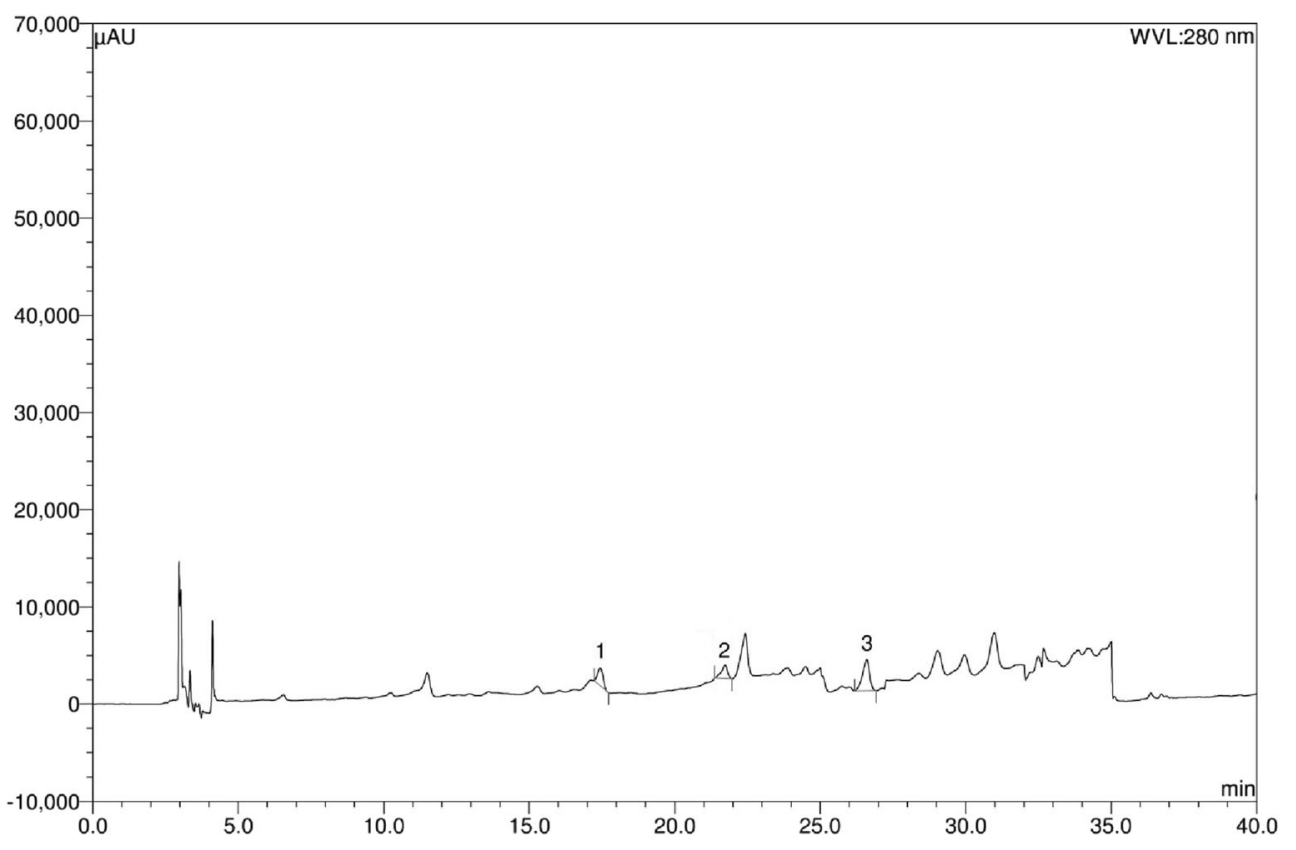

flavanols, namely, (+)-catechin, and (-)-epicatechin were detected in Ajwah and Safawy extracts. Neuroprotective effect of these two flavonols is well established and the mechanism of action is believed to be their antioxidant activity and beneficial actions on brain cells which include positive effects on mood (Mandel and Youdim 2004; Nehlig 2013). Although neuroprotection by hydroxycinnamic acids can be much less as compared to catechins, the effect of trans-ferulic acid cannot be ruled out since it is reported to exert neuroprotective effect in in-vivo and in-vitro tests and its antioxidant capacity might be the contributing factor for such activity (Cheng et al. 2008; Luo and Sun 2011; Wu et al. 2014). The traditional use of date plam in headache prompted us to test the extracts for antinociceptive activity. Decrease in the writhing in acetic acid induced writhing test suggests that date extracts can show analgesia through peripheral mechanism of pain inhibition, i.e., block inflammatory pathway of pain sensation through the inhibition of prostaglandin synthesis (Murata et al. 1997). This is in agreement with previous finding in which methanol extract of Zaghlool dates showed anti-inflammatory activity in rat model (Mohamed and Al-Okabi 2004). An increase in the response time in hot plate test further suggests that the observed analgesia might also involve centrally acting mechanism (Wigdor and Wilcox 1987). In different studies,
Fig. 5 HPLC chromatogram of Sukkari date extract. Peaks 1: caffeic acid; 2: $p$-coumaric acid; 3: trans-ferulic acid

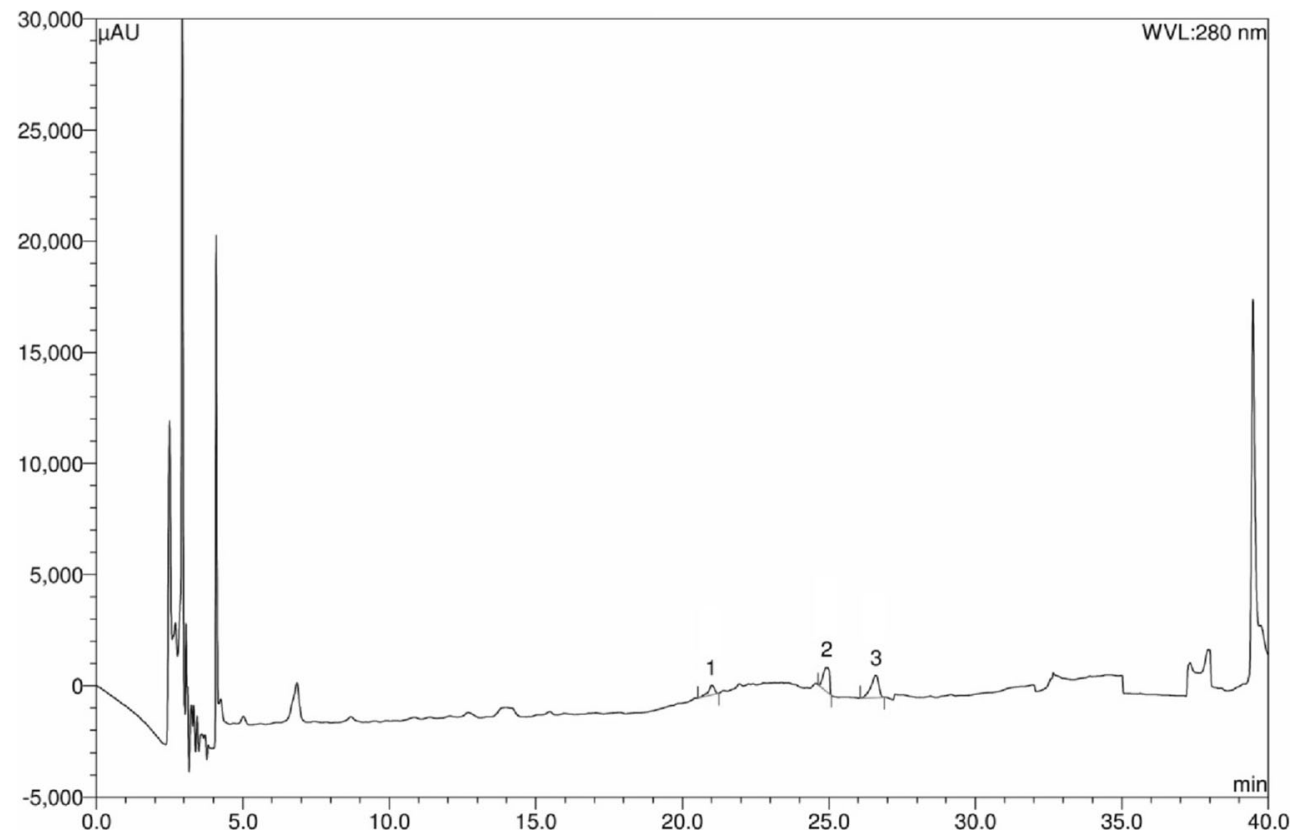


Table 6 Contents of polyphenolic compounds in three date extracts

\begin{tabular}{llll}
\hline $\begin{array}{l}\text { Polyphenolic } \\
\text { compound }\end{array}$ & \multicolumn{2}{l}{ Content in $\mathrm{mg} / 100 \mathrm{~g}$ of dry extract*(\% RSD) } \\
\cline { 2 - 4 } & Ajwah & Safawy & Sukkari \\
\hline trans-Ferulic acid & $11.70(0.18)$ & $5.01(0.06)$ & $2.28(0.06)$ \\
$(+)-C a t e c h i n$ & $14.67(0.29)$ & $42.25(0.57)$ & - \\
$(-)$-Epicatechin & $9.15(0.11)$ & $21.93(0.34)$ & - \\
Rosmarinic acid & $3.73(0.04)$ & - & - \\
Caffeic acid & - & - & $3.11(0.09)$ \\
$p$-Coumaric acid & - & - & $1.37(0.05)$ \\
\hline
\end{tabular}

$* n=5 ; R S D$ Relative standard deviation

trans-ferulic acid has showed analgesic activity in thermal hyperalgesia, acetic acid induced writhing and mechanical allodynia tests in mice (Lv et al. 2013; Ozaki 1992). Thus, transferulic acid could be credited to some extent for the observed analgesic activity of the date extracts. In addition, more potent activity of Ajwah compared to the two other date cultivars might be due to the higher content of trans-ferulic acid in Ajwah. (+)Catechin, and (-)-epicatechin, detected in Ajwah and Safawy extracts are also reported to show anti-inflammatory activity in various in-vivo and in-vitro models including inhibition of $\mathrm{NO}$ production and LPS-induced prostaglandin E2 release (García et al. 2013; Wang and Cao 2014; Yang et al. 2015).

\section{Conclusion}

Present investigation suggests that Ajwah, Safawy and Sukkari cultivars of date palm have some degree of relaxing effect on the brain. It is possible that these extracts reduce CNS activity resulting in decreased locomotor activity in test mice. The extracts also produced analgesic activity in test mice supporting its use in headache in traditional medicine. However, in all cases, the effect was not as strong as that of the positive control, indicating a moderate level of neuropharmacological and analgesic activity, and thus could be of interest for producing mild relaxing effect on the brain. The effects were similar with all the three date cultivars, but relatively stronger with Ajwah dates.

Acknowledgments We are grateful to Al-Moalim MA BinLaden chair for Scientific Miracles of Prophetic Medicine (MABL) for providing financial support (research grant no. MABL 37/02) and Pharmacy Discipline, Khulna University, Bangladesh for laboratory facilities to conduct bioactivity studies.

\section{Compliance with ethical standards}

Ethical statement The experimental protocols were approved by the Ethical Committee of Pharmacy Discipline, Life Science School, Khulna University, Bangladesh.

Conflict of Interest The authors declare no conflict of interests.
Open Access This article is distributed under the terms of the Creative Commons Attribution 4.0 International License (http://creativecommons.org/ licenses/by/4.0/), which permits unrestricted use, distribution, and reproduction in any medium, provided you give appropriate credit to the original author(s) and the source, provide a link to the Creative Commons license, and indicate if changes were made.

\section{References}

Abuharfeil NM, Sukhon SE, Msameh Y, Sallal A-KJ (1999) Effect of date fruits, Phoenix Dactyliferia L., on the hemolytic activity of Streptolysin O. Pharm Biol 37:335-339

Al-Farsi M, Alasalvar C, Morris A, Baron M, Shahidi F (2005) Compositional and sensory characteristics of three native sun-dried date (Phoenix dactylifera L.) varieties grown in Oman. J Agric Food Chem 53:7586-7591

Al-Maiman SA (2005) Effect of date palm (Phoenix dactylifera) seed fibers on plasma lipids in rats. J King Saud Univ Agric Sci 17:117-123

Al-Qarawi AA, Mousa HM, Ali BH, Abdel-Rahman H, El-Mougy SA (2004) Protective effect of extracts from dates (Phoenix dactylifera L.) on carbon tetrachloride-induced hepatotoxicity in rats. Int J Appl Res Vet Med 2:176-180

Al-Qarawi A, Abdel-Rahman H, Ali B, Mousa H, El-Mougy S (2005) The ameliorative effect of dates (Phoenix dactylifera L.) on ethanolinduced gastric ulcer in rats. J Ethnopharmacol 98:313-317

Al-Qarawi A, Abdel-Rahman H, Mousa H, Ali B, El-Mougy S (2008) Nephroprotective action of Phoenix dactylifera. in gentamicininduced nephrotoxicity. Pharm Biol 46:227-230

Baliga MS, Baliga BRV, Kandathil SM, Bhat HP, Vayalil PK (2011) A review of the chemistry and pharmacology of the date fruits (Phoenix dactylifera L.). Food Res Int 44:1812-1822

Bauza E, Dal Farra C, Berghi A, Oberto G, Peyronel D, Domloge N (2001) Date palm kernel extract exhibits antiaging properties and significantly reduces skin wrinkles. Int J Tissue React 24:131-136

Cheng CY, Su SY, Tang NY, Ho TY, Chiang SY, Hsieh CL (2008) Ferulic acid provides neuroprotection against oxidative stress-related apoptosis after cerebral ischemia/reperfusion injury by inhibiting ICAM-1 mRNA expression in rats. Brain Res 1209:136-150

Chuanphongpanich S, Phanichphant S (2006) Method development and determination of phenolic compounds in broccoli seeds samples. Chiang Mai J Sci 33:103-107

El-Ameen NMH, Taha MME, Abdelwahab SI, Khalid A, Elfatih F, Kamel MA, Sheikh BY (2015) Anti-diabetic properties of thymoquinone is unassociated with glycogen phosphorylase inhibition. Phcog J 7:406-410

El-Mougy S, Abdel-Aziz S, Al-Shanawany M, Omar A (1991) The gonadotropic activity of Palmae in mature male rats. Alex J Pharm Sci 5:156-159

ffrench-Mullen JM, Barker JL, Rogawski MA (1993) Calcium current block by (-)-pentobarbital, phenobarbital, and CHEB but not (+)-pentobarbital in acutely isolated hippocampal CA1 neurons: comparison with effects on GABA-activated Cl- current. J Neurosci 13:3211-3221

García M, Michelangeli F, Fernández Á, Villamizar JE, Salazar F, Taylor P (2013) Anti-inflammatory effects of (+)-catechin isolated from the bark of Byrsonima crassifolia. Planta Med 79:PF12

Giacalone M, Di Sacco F, Traupe I, Topini R, Forfori F, Giunta F (2011) Antioxidant and neuroprotective properties of blueberry polyphenols: a critical review. Nutr Neurosci 14:119-125

Gill L (1992) Ethnomedical uses of plants in Nigeria. Uniben Press, Benin

Guido F et al. (2011) Chemical and aroma volatile compositions of date palm (Phoenix dactylifera L.) fruits at three maturation stages. Food Chem 127:1744-1754 
Halabi MF, Sheikh BY (2014) Anti-proliferative effect and phytochemical analysis of Cymbopogon citratus extract. BioMed Res Int 2014: 906239

Hmamouchi M (1999) Les plantes médicinales et aromatiques marocaines: utilisation, biologie, écologie, chimie, pharmacologie, toxicologie, lexiques. Imprimerie de Fédala, Mohammedia

Hong YJ, Tomas-Barberan FA, Kader AA, Mitchell AE (2006) The flavonoid glycosides and procyanidin composition of Deglet Noor dates (Phoenix dactylifera). J Agric Food Chem 54:2405-2411

Ishurd O, Kennedy JF (2005) The anti-cancer activity of polysaccharide prepared from Libyan dates (Phoenix dactylifera L.). Carbohydr Polym 59:531-535

Islam MK et al. (2014) Antinociceptive and antioxidant activity of Zanthoxylum budrunga Wall (Rutaceae) seeds. Sci World J 2014: 869537

Jassim SA, Naji MA (2010) In vitro evaluation of the antiviral activity of an extract of date palm (Phoenix dactylifera L.) pits on a Pseudomonas phage. Evid Based Complement Alternat Med 7: $57-62$

Kalantaripour T, Asadi-Shekaari M, Basiri M, Najar AG (2012) Cerebroprotective effect of date seed extract (Phoenix dactylifera) on focal cerebral ischemia in male rats. J Biol Sci 12:180-185

Katsumichi M, Ryuichi M, Nobuki M (1997) Pulverized dried plants as sleeping aids. Japanese patent, JP 09023851, Available from SciFinder Scholar (25 June 2015)

Kikuchi N, Miki T (1978) The separation of date (Phoenix dactylifera) sterols by liquid chromatography. Microchim Acta 69:89-96

Lorke D (1983) A new approach to practical acute toxicity testing. Arch Toxicol 54:275-287

Luo L, Sun Y (2011) Neuroprotective effect of ferulic acid in vitro. Zhong Yao Cai 34:1750-1753

Lv WH, Zhang L, Wu SJ, Chen SZ, Zhu XB, Pan JC (2013) Analgesic effect of ferulic acid on $\mathrm{CCl}$ mice: behavior and neurobiological analysis. Zhongguo Zhong Yao Za Zhi 38:3736-3741

Mandel S, Youdim MBH (2004) Catechin polyphenols: neurodegeneration and neuroprotection in neurodegenerative diseases. Free Radic Biol Med 37:304-317

Mansouri A, Embarek G, Kokkalou E, Kefalas P (2005) Phenolic profile and antioxidant activity of the Algerian ripe date palm fruit (Phoenix dactylifera). Food Chem 89:411-420

Maulidiani M, Sheikh BY, Mediani A, Wei LS, Ismail IS, Abas F, Lajis NH (2015) Differentiation of Nigella sativa seeds from four different origins and their bioactivity correlations based on NMRmetabolomics approach. Phytochem Lett 13:308-318

Mohamadin AM, Sheikh B, El-Aal AAA, Elberry AA, Al-Abbasi FA (2010) Protective effects of Nigella sativa oil on propoxur-induced toxicity and oxidative stress in rat brain regions. Pestic Biochem Physiol 98:128-134

Mohamed DA, Al-Okabi S (2004) In vivo evaluation of antioxidant and anti-inflammatory activity of different extracts of date fruits in adjuvant arthritis. Pol J Food Nutr Sci 13:397-402

Mondal $\mathrm{H}$ et al. (2014) Central-stimulating and analgesic activity of the ethanolic extract of Alternanthera sessilis in mice. BMC Complement Altern Med 14:398

Murata T et al. (1997) Altered pain perception and inflammatory response in mice lacking prostacyclin receptor. Nature 388:678-682

Nehlig A (2013) The neuroprotective effects of cocoa flavanol and its influence on cognitive performance. Br J Clin Pharmacol 75:716727

Ozaki Y (1992) Antiinflammatory effect of tetramethylpyrazine and ferulic acid. Chem Pharm Bull 40:954-956

Pujari RR, Vyawahare NS, Kagathara VG (2011) Evaluation of antioxidant and neuroprotective effect of date palm (Phoenix dactylifera $\mathrm{L}$.) against bilateral common carotid artery occlusion in rats. Indian $\mathrm{J}$ Exp Biol 49:627-633

Puri A, Sahai R, Singh KL, Saxena R, Tandon J, Saxena K (2000) Immunostimulant activity of dry fruits and plant materials used in Indian traditional medical system for mothers after child birth and invalids. J Ethnopharmacol 71:89-92

Selvam A (2008) Inventory of vegetable crude drug samples housed in botanical survey of India, Howrah. Pharmacogn Rev 2:61-94

Shanmugapriya M, Patwardhan K (2012) Uses of date palm in Ayurveda. In: Manickavasagan A, Essa MM, Sukumar E (eds) Dates: production, processing, food, and medicinal values. CRC Press, Boca Raton, pp. 377-385

Sheikh BY, Mohamadin AM (2012) Thymoquinone a potential therapy for cerebral oxidative stress. Asian J Nat Appl Sci 1:76-92

Sheikh BY, Elsaed WM, Samman AH, Sheikh BY, Ladin A-MMB (2014) Ajwa dates as a protective agent against liver toxicity in rat. Eur Sci J 10:358-368

Shilpi JA, Uddin SJ, Rouf R, Billah MM (2004) Central nervous system depressant activity of Diospyros peregrina bark. Orient Pharm Exp Med 4:249-252

Shraideh ZA, Abu-Elteen KH, Sallal A-KJ (1998) Ultrastructural effects of date extract on Candida albicans. Mycopathologia 142:119-123

Taha MME et al. (2015) Effectiveness of Sidr Honey on the prevention of ethanol-induced gastroulcerogenesis: role of antioxidant and antiapoptotic mechanism. Phcog J 7:157-164

Takagi K, Wantanabe M, Saito H (1971) Studies of the spontaneous movement of animals by the hole cross test; effect of 2-dimethylaminoethanol and its acyl esters on the central nervous system. Jpn J Pharmacol 21:797-810

Tian Y (2014) A seaweed-blueberry compound beverage and processing method. Chinese patent, CN 103989221, Available from SciFinder Scholar (25 June 2015)

Uddin S, Shilpi J, Rahman M, Ferdous M, Rouf R, Sarker S (2006) Assessment of neuropharmacological activities of Pandanus foetidus (Pandanaceae) in mice. Pharmazie 61:362-364

Vayalil PK (2002) Antioxidant and antimutagenic properties of aqueous extract of date fruit (Phoenix dactylifera L. Arecaceae). J Agric Food Chem 50:610-617

Wang H, Cao Z (2014) Anti-inflammatory Effects of (-)-epicatechin in lipopolysaccharide-stimulated RAW 264.7 macrophages. Trop J Pharm Res 13:1415-1419

Wang JY, Wen LL, Huang YN, Chen YT, Ku MC (2006) Dual effects of antioxidants in neurodegeneration: direct neuroprotection against oxidative stress and indirect protection via suppression of gliamediated inflammation. Curr Pharm Des 12:3521-3533

Wigdor S, Wilcox GL (1987) Central and systemic morphine-induced antinociception in mice: contribution of descending serotonergic and noradrenergic pathways. J Pharmacol Exp Ther 242:90-95

$\mathrm{Wu}$ W et al. (2014) Neuroprotective ferulic acid (FA)-glycol chitosan (GC) nanoparticles for functional restoration of traumatically injured spinal cord. Biomaterials 35:2355-2364

Yang DJ, Liu SC, Chen YC, Hsu SH, Chang YP, Lin JT (2015) Three pathways assess anti-inflammatory response of epicatechin with lipopolysaccharide-mediated Macrophage RAW 264.7 Cells. J Food Biochem 39:334-343

Zaid A, Arias-Jiménez EJ (2002) Date palm cultivation. Rome: United Nations FAO plant production and protection (http://www.fao. org/docrep/006/y4360e/y4360e00.HTM, accessed on 10 Dec 2015)

Ziyyat A, Legssyer A, Mekhfi H, Dassouli A, Serhrouchni M, Benjelloun W (1997) Phytotherapy of hypertension and diabetes in oriental Morocco. J Ethnopharmacol 58:45-54 